\title{
GABRIELA MISTRAL: RECADOS DE LA ALDEA
}

\author{
Leonidas Morales T. \\ Universidad de Chile \\ 1moralest@vtr.net
}

RESUMEN / ABSTRACT

El ensayo examina uno de los géneros de la oralidad en la palabra en Gabriela Mistral, el recado, y la naturaleza de su cristianismo social, vías que conducen a su visión de la aldea en la que se confunden la memoria biográfica con imágenes y valores bíblicos. A partir de aquí, el ensayo analiza la crítica de Mistral a la vida cotidiana chilena moderna, para detenerse finalmente en la crítica a la política de los gobiernos republicanos frente al pueblo mapuche, una política de represión y destrucción de la aldea indígena, hermana de su aldea de la infancia.

PALABRAS ClaVE: recado, cristianismo, aldea, crítica.

This essay examines one of the genres of orality in Gabriela Mistral, the "recado", and the nature of its social Christianity, both of which lead us to her vision of the village that merges biographical memory along with biblical images and values. From this standpoint, the essay analyses Mistral's critique of modern everyday Chilean life to finally determine a criticism of the policies set by Republican governments to deal with the Mapuche people, policies which bespeak of repression and destruction of the indigenous village, akin to Mistral's childhood village.

KEY WORDS: “recado”, Christianity, village, criticism.

En 1921, poco antes de su viaje a México en 1922 (y con él el inicio de largas ausencias de su país), Gabriela Mistral comienza también a publicar artículos en El Mercurio y luego en otros periódicos y revistas de Hispanoamérica. 
El título de muchos de ellos los encabezó con la palabra "recado", seguida de un "para" (tal o cual persona) o de un "sobre" (tal o cual tema). Por ejemplo, "Recado para Julio Barrenechea" o "Recado sobre Pablo Neruda". En 1957, el mismo año de su muerte, Alfonso Escudero reúne un número importante de sus escritos de prensa y los publica con el título de Recados contando a Chile. Un título a mi parecer feliz. Si bien no todos los escritos periodísticos incluidos llevan en su título original la palabra recado, todos admiten sin embargo su lectura bajo la identidad discursiva propia de un recado. Ninguno cae tampoco fuera del orden temático dominante: el de la realidad chilena, cualquiera sea el aspecto particular tratado en cada uno de ellos (político, histórico, cultural, literario, poético, etc.). Es además un título feliz el de Escudero porque al introducir el adverbio "contando" (a Chile), da cuenta, en los textos de Gabriela Mistral compilados, de un modo constante de referencia a la realidad de Chile por parte de su autora: el modo según el cual lo que cada cosa es, es lo que cabe "contar" de cada una de ellas. Como si de la esencia de las cosas (de su identidad) solo fuera posible hablar en términos narrativos.

El recado es sin duda una de las tantas prácticas discursivas mediante las cuales opera la comunicación verbal cotidiana. Cual sea su diferencia, queda a la vista si reparamos en su etimología: la palabra recado significa "mensaje". Pero no un mensaje de transmisión lineal, es decir, entregado o enviado directamente por su emisor a su destinatario, sino un mensaje como "comisión" (Corominas 484), o mejor, comisionado, entendiendo por comisionado "encargado". El significado del recado introduce pues, necesariamente, un tercero de la comunicación: un intermediario. Es en definitiva un mensaje que un emisor envía a un destinatario a través de alguien (un encargado o comisionado). En el caso concreto de los recados de Gabriela Mistral, el intermediario es el periódico donde aparecen publicados (o el libro que los recopila). El destinatario real o efectivo de los recados no puede ser sino el lector del periódico que los publica (o del libro que los reúne). Lo cual resulta del todo evidente en aquellos que solo especifican el tema ("Recado sobre el mar y sobre un contador del mar"), donde no está postulado formalmente un destinatario como tal y el espacio de su ausencia lo ocupa el lector del periódico (o del libro). Y cuando algunos de estos recados nombra a su destinatario ("para" Julio Barrenechea, "para" Inés Puyó), el nombre se convierte propiamente en un destinatario retórico: en un mero signo de reconocimiento y de delimitación de un objeto temático. 
La crítica literaria sobre Gabriela Mistral suele darle al recado en tanto práctica discursiva un tratamiento conceptualmente no definido, ambiguo por lo mismo. ¿Es un género el recado? La pregunta tiene sentido puesto que todo género es una clase de discurso, y el recado, ya lo vimos, evidentemente lo es. Pero, por otra parte, la teoría contemporánea de los géneros establece ${ }^{1}$, de manera explícita o no, una condición inexcusable de toda genericidad: para que una clase de discurso sea considerada propiamente un género (sea o no un género literario, sea o no de ficción), debe exhibir siempre un origen y una trayectoria de carácter histórico. En otras palabras, ser una clase de discurso que emerge y se configura en el tiempo de una cultura dada, que en ese tiempo se transforma y que en él puede también llegar a desaparecer. El diario íntimo o el reportaje, entre los géneros referenciales, o el cuento y la novela, entre los de ficción, no solo son géneros de origen y trayectoria históricos, sino que son además géneros modernos: tal como los conocemos hoy no existían ni existen antes ni fuera de la cultura moderna.

Evidentemente no es este el caso del recado. Por lo pronto, no cumple con la condición de historicidad. Al revés, representa una clase de discurso transhistórico: como recurso verbal de la comunicación cotidiana, ha estado siempre ahí, disponible desde que hay un yo hablante o usuario de una lengua, de cualquier lengua y en cualquiera de sus momentos sucesivos. Desde luego, el recado no está solo: a su misma clase pertenecen también otros discursos, como el "testimonio". Ahora bien, estos discursos desprovistos de marcas genéricas aparecen de hecho en el interior de otras clases de discurso que sí son géneros, incidiendo incluso en el sentido mismo de la forma específica que adopta su discursividad. Sobre todo el testimonio, de presencia tan común en los géneros biográficos (autobiografía, memorias, diario íntimo, carta). Si bien el recado no goza del mismo privilegio de presencia, tampoco pesa sobre él una exclusión total. La prueba: los textos reunidos en los Recados contando a Chile de Gabriela Mistral. Aquí, el género de acogida de los recados y bajo el cual fueron publicados en diarios y revistas, es la crónica urbana. En la actualidad, uno de los más importantes entre los géneros periodísticos (junto con la entrevista y el reportaje).

No es de extrañar esta "cohabitación" de recado y crónica. Uno de los rasgos semánticos esenciales del concepto de recado es la estricta puntualidad de su mensaje, en tiempo y espacio, reforzado en general por un sentido de

\footnotetext{
${ }^{1}$ Ver en bibliografía compilación de Miguel Garrido Gallardo (1988).
} 
urgencia (a veces de extrema urgencia): "esto, y sobre esto, te mando decir, hoy, para que actúes en consecuencia". Desde este punto de vista, hay una manifiesta complicidad entre recado y crónica urbana. La crónica es un género también definido por una puntualidad paralela que, en su caso, toma la forma de una apertura a la cotidianidad noticiosa, a los sucesos (políticos, sociales, culturales) del día tras día, a la transitoriedad del tiempo moderno que rige la vida en los espacios urbanos (aun cuando la puntualidad de la crónica tenga ramificaciones y ecos que rebasan los límites, con frecuencia domésticos, de la comunicación del recado). En cualquier caso, es en la puntualidad de la crónica donde se inscribe la puntualidad del recado, expandiendo así el horizonte de su recepción. Ahora bien, puede decirse asimismo que la crónica, al acoger en su espacio el nombre o el espíritu del recado, se vuelve más íntima, más "personal", haciendo suyo el gesto de inmediatez, de cercanía y de apelación a un tú propio del recado. De todas maneras, en su tránsito hacia la crónica, el recado, por una parte, pierde la singularidad de su emisor y de su receptor, y, por otra, al aparecer bajo la forma de la escritura impresa, inherente al periódico, se pone a gran distancia de su origen oral.

Este aspecto, el de la oralidad del recado, es de mención especialmente oportuna tratándose de Gabriela Mistral y de la composición de su lenguaje (tanto el de la prosa como el de su poesía). Acabo de decirlo: al acogerse al género de la crónica, el recado asume su condición de escritura periodística. Pero la escritura, para el recado, no es más que un accidente en su vida discursiva, que para nada altera su identidad de origen. En efecto, como clase de discurso transhistórico, el recado es anterior a la invención de la técnica de la escritura (patrimonio de muy pocas culturas y solo generalizada en la fase de globalización de la cultura moderna), y, si bien un emisor "letrado" puede darle una forma escrita, donde mejor mantiene su espíritu y cumple sus viejas funciones de comunicación cotidiana es fuera de la escritura, es decir, en los espacios sociales y culturales de dominio de la oralidad.

Es de conocimiento común entre sus lectores y críticos, que Gabriela Mistral mantuvo siempre una relación de identificación gozosa con el mundo de su infancia, es decir, el de la vida familiar y el de las pequeñas comunidades de los pueblos del Valle de Elqui en la Provincia de Coquimbo. Un mundo ese regido por la cultura de la oralidad, inseparable de gestos, modos y valores comunitarios o tradicionales. La palabra de su poesía y su prosa remite al mundo de la oralidad. Pero el modo de la remisión a ese mundo, se sabe también, no es el de la estética sumisa de una mímesis lineal (un peso muerto que carga a veces el lenguaje literario de algunos de sus contemporáneos 
"criollistas"): la palabra de la oralidad entra en el lenguaje de Gabriela Mistral (el de su poesía y el de su prosa) mediada por una fuerte torsión intelectual, por una poética que, sin anular la posibilidad de su reconocimiento como palabra oral, la procesa (su forma y su contexto) y la resitúa en el discurso dándole al mismo tiempo una identidad intensamente barroca. Sus Recados contando a Chile ilustran muy bien estos dos aspectos: la remisión a una oralidad originaria y el sometimiento de esta oralidad a una operación estética que la reconfigura en función de otra verdad que es la de otra ética.

Si bien el libro Recados contando a Chile incluye crónicas publicadas hasta la década del 50, las primeras, las de la década del 20 y del 30, contienen ya la singularidad de la mirada de Gabriela Mistral. Se trata de una mirada eminentemente crítica sobre la realidad chilena (social, política, cultural). Las excepciones (que veremos más adelante, en el apartado 3) no son sino celebración de la diferencia dentro de una constante. Tanto la postura crítica como sus temas tienen condicionamientos históricos, perceptibles por el lector como supuestos del discurso o como referentes explícitos del mismo, y todos asociados a un determinado momento del desarrollo de la modernidad (europea y latinoamericana), complejo y múltiple como todos los momentos coyunturales por los que ha transitado estructuralmente el orden social, político y cultural burgués (que al final es el tránsito de un estado a otro de producción y circulación de la mercancía y su consumo).

Ese momento coincide con el fin de la "belle époque" (precipitado por la guerra del 14), la agitación de movimientos sociales populares (anarquistas, comunistas) en torno a la utopía de una "sociedad nueva", movimientos éstos paralelos a la agitación vanguardista en torno a otra utopía paralela, la de un "arte nuevo" reconciliado con la vida cotidiana, y en general con la emergencia, antes, durante y después de la Primera Guerra Mundial, de un pensamiento que en sus diversas esferas de prácticas discursivas (política, filosofía, arte, literatura) radicaliza sus preguntas y sus respuestas sobre el pasado, el presente y el futuro de la sociedad moderna. En el caso particular de América Latina, y concretamente en el terreno de la literatura y la reflexión cultural, hay que subrayar además, dentro de los condicionamientos históricos, la relevancia del paso del "modernismo" finisecular, seducido por modelos y motivos europeos, sobre todo parisinos, a una nueva ética y a una nueva 
política, abiertas ahora a la percepción de lo propio, es decir, de las identidades sociales y culturales propiamente latinoamericanas. El juicio de Mistral sobre Francia será en este sentido lapidario: ella "es algo así como el opio de la humanidad y, sobre todo, de la juventud; adormece, corrompe, desgaja a los mejores talentos literarios" 2 . Estamos de vuelta pues del ciclo francés, de cuando París era "la capital del siglo XIX" (Benjamin).

En una primera definición, diría: la mirada crítica de Gabriela Mistral es la de un testigo de la vida cotidiana chilena de la primera mitad del siglo $\mathrm{XX}$, cuyo testimonio, el de los Recados, está mediado sin embargo, en su enunciación, por la memoria y por la ausencia del país ${ }^{3}$. Es un testimonio del devenir de esa vida cotidiana como devenir de una sociedad y una cultura, de sus procesos de transformación, de los modelos que los presiden, de las tensiones y expectativas que los acompañan. En resumen, testimonio de la singularidad de esa sociedad y de esa cultura tal como los sujetos de su vida cotidiana la ponen en escena en un momento de su historia. Ponerla en escena, es decir, actuarla. Solo que no estamos frente a una actuación por completo abierta o imprevisible, sin "guión" (sin "texto dramático"). Siempre hay un guión, más allá de si, en los extremos, la actuación lo sigue al pie de la letra o lo subvierte, y quien lo escribe (y reescribe incesantemente) es el poder. El guión despliega las "estrategias" mediante las cuales el poder se legitima y se reproduce. Son por lo mismo de naturaleza ideológica y están destinadas a distribuir roles, a "repartir" espacios, fijar límites. Terry Eagleton presenta un cuadro sumario de estas estrategias: "Un poder dominante se puede legitimar por sí mismo promocionando creencias y valores afines a él; naturalizando y universalizando tales creencias para hacerlas evidentes y aparentemente inevitables; denigrando ideas que puedan desafiarlo; excluyendo formas contrarias de pensamiento, quizá por una lógica tácita pero sistemática; y oscureciendo la realidad social de modo conveniente a sí misma" (Eagleton 24).

Por lo tanto, si la crítica de Gabriela Mistral a la cotidianidad chilena, social y cultural, es una crítica de verdad (que sí lo es), necesariamente tiene que terminar siendo, de una u otra manera, una crítica a las estrategias de un poder dominante. Y si estas estrategias, por ser ideológicas, son las

${ }^{2}$ Carta dirigida a Pedro Moral, fundador del Museo Gabriela Mistral de Vicuña, reproducida por Matilde Ladrón de Guevara, 98 y s.

${ }^{3}$ Retomaré al final de este ensayo el problema de la memoria y los largos años de ausencia de Chile de Gabriela Mistral, y su importancia literaria. 
de un discurso que para no delatarse debe permanecer opaco, encubierto, el resultado de la crítica de Gabriela Mistral, la de sus Recados, no puede ser otra cosa que lo que efectivamente es: un hacer visible lo invisible, un poner de relieve lo que se minimiza o un conectar tales o cuales efectos a tales o cuales causas mantenidas calladas, ocultas o disfrazadas. Así, en la sucesión de estos mensajes, el movimiento de la crítica va dejando en estado de exposición ante el lector aquellos núcleos temáticos a la vez recurrentes y piedras angulares del pensamiento de Mistral, por ejemplo, el de la defensa del débil (el campesino, la mujer, el indígena) frente al poder y los poderosos. Insisto: la palabra de estos mensajes nunca abandona la oralidad y el coloquialismo, ni el carácter concreto del tema, siempre situado (en tiempo y espacio), propios de la palabra del recado.

Sin duda son, en primer lugar, los lectores chilenos a quienes ella les "cuenta" el Chile que ve y comprende. Es a ellos, para empezar, a quienes concierne el recado y su mensaje crítico. Y son ellos los invitados a leer en cada uno de sus mensajes juicios, descripciones e imágenes sobre la sociedad que habitan, instándolos implícitamente a la vez a hacerse cargo de tales juicios, descripciones e imágenes en cuanto revelan, desde el punto de vista ético, el peligro de una degradación del sujeto y de las relaciones intersubjetivas por desidia culpable, por políticas incompatibles, funcionales a otros objetivos. En la palabra y la entonación de estos mensajes mistralianos el lector adivina el gesto inconfundible que asociamos con quien ofrece un consejo, sin que parezca impertinente, o hace un llamado de atención, sin que resulte autoritario, o transmite una enseñanza, sin que a ésta la desnaturalice el dogmatismo. En resumen: el gesto de alguien que se siente no solo solidario de un destino social y cultural colectivo sino responsable del mismo. Es el gesto, por último, de una pedagogía. El gesto pues de un educador. Tal vez Gabriela Mistral sea la última gran escritora chilena (y latinoamericana) que prolonga durante la primera mitad del siglo XX el gesto de esa palabra educadora que pasa por Sarmiento y se perfecciona con Martí, grandes maestros y orientadores suyos.

Ahora bien, ¿desde dónde hace su crítica social y cultural Gabriela Mistral? ¿Desde qué paradigma de valores y de conceptos? Los primeros recados entre los reunidos por Escudero en su edición de 1957 son, dijimos, de comienzos de la década del 20. Muy cerca entonces de la Revolución rusa de 1917, que provocó una conmoción política generalizada mostrando una dirección viable a la crítica al poder burgués y sus estrategias ideológicas, es decir, un modo posible de anclaje histórico al horizonte de expectativas de liberación popular. ¿Tuvo alguna acogida la Revolución rusa, sus principios, 
su metodología, su programa, en la crítica de Gabriela Mistral? No hay textos suyos que lo confirmen. Pero tampoco puede decirse que haya ignorado aquel acontecimiento, tan fundamental para el pensamiento político y social de las décadas de 1910 y 1920, decisivo asimismo para la historia posterior de los movimientos de liberación y, como antagonista, para el propio proyecto burgués o capitalista. En efecto, no solo no lo ignoró sino que lo asumió explícitamente en tanto objeto de reflexión. Pero será una reflexión de la cual rápidamente saldrán a la superficie diferencias irreconciliables en aspectos esenciales.

En 1924 visita Estados Unidos por primera vez. Publica allí una crónica con el título de "Cristianismo con sentido social". El tema de fondo es el reconocimiento, amargo para ella, de que el cristianismo latinoamericano "ni por tradición ni por cálculo sagaz (...) ha sabido ser leal con los humildes”. ¿Cómo llenar ese largo vacío de desatención social, una tarea urgente por lo demás? ¿Es deseable el modelo de la Revolución rusa? Gabriela Mistral, en este punto, no analiza ni discute la teoría (principios y métodos) de la experiencia política rusa. Pero sí toma posición frente a ella. Para decidirla, le bastan algunas evidencias en el terreno de las prácticas. Comienza citando lo que probablemente es una noticia periodística: "en la Navidad del año pasado, recorrió las calles de Petrogrado una procesión grotesca, en la que los fundadores de las religiones, Cristo entre ellos, iban personificados con mamarrachos". A partir de aquí, su discurso genera connotaciones incluso prejuiciosas, hasta entra en asociaciones con algunos de los lugares comunes de la propaganda reaccionaria, y todo en torno a una condena radical de la Revolución rusa: habla de ella como de "la dictadura rusa aterrorizante", de sus protagonistas, como de una "horda tártara", y de quienes son sus seguidores en otras partes del mundo, como de los "discípulos de la estepa" (Mistral, "Cristianismo con sentido social". Prosa religiosa 35 y 38).

Es que para ella una revolución (o cualquier proyecto político-social libertario y de justicia) se deslegitima si no hace posible el cultivo de una dimensión inexcusable del sujeto humano: la religiosidad. El título de una conferencia suya anterior a la crónica de 1924 era precisamente "El sentido religioso de la vida". Explicaba allí lo que entendía por religioso o religiosidad poniendo de ejemplo a los artistas: cuando éstos son religiosos "tienen al mirar el mundo exterior la intuición del misterio, y saben que la rosa es algo más que una rosa y la montaña algo más que una montaña; ven el sentido místico de la belleza y hallan en las suavidades de la hierba y de las nubes del verano la insinuación de una mayor suavidad, que está en las yemas de 
$\operatorname{Dios}^{4 "}$. Potenciar el sentido religioso en el hombre es potenciar el sentido trascendente de la vida y su destino como desarrollo espiritual: "El fin de la vida entera no es otro que el desarrollo del espíritu humano hasta su última maravillosa posibilidad" (Mistral, "El sentido religioso de la vida", 27-28). Una revolución o un proyecto social que excluya esta religiosidad significaría proponer un hombre vacío de espiritualidad y por lo tanto empobrecido, barbarizado e infiel a sí mismo.

La crítica de Gabriela Mistral a la vida cotidiana chilena procede en efecto según un paradigma religioso. Este paradigma religioso admite una determinación más precisa: es "cristiano". Pero de un cristianismo no excluyente ni dogmático, independiente frente a la Iglesia Católica: se conoce bien en este plano su temprano interés por la teosofía, el budismo y otras expresiones del pensamiento hindú, incluyendo la poesía (Tagore). La propia Mistral se definía a sí misma como "cristiana" y no como "católica" ¿. ¿En qué consiste su cristianismo? Su paradigma, en este punto, es directamente tributario de toda una constelación de ejemplaridades, éticas y, como tales, capaces de condicionar la aceptabilidad de las formas sociales o culturales, tanto las históricas como las utópicas. Esas ejemplaridades remiten, esencialmente, a los grandes relatos y a las grandes figuras bíblicas (Cristo ante todo, y con él, David, Elías, Job, Ruth), a la historia del pueblo judío (para ella historia emblemática del perseguido, del excluido), a las vidas de santos de los tiempos posteriores, del Medioevo (San Francisco), del barroco (Santa Teresa, San Juan de la Cruz). La Biblia misma, como libro, representa para Mistral una ejemplaridad superior e incomparable: la de una escritura veraz, intensa, poética, "realista" y comunitaria ${ }^{6}$.

${ }^{4}$ La idea de que las cosas no se cierran sobre sí mismas, que hay "algo más" en cada una de ellas, un horizonte lejano sobre el que se proyectan y de donde proviene su "misterio", no está lejos de lo que Benjamin, en la década de 1930, llamará el "aura" de las cosas, también asociada a lo religioso (La obra de arte en la época de su reproductibilidad técnica).

5 Sobre su manera de entender el cristianismo y sus simpatías budistas, ver Matilde Ladrón de Guevara, 47-48.

${ }^{6}$ Gabriela Mistral describe muy bien sus lecturas de la Biblia desde muy temprana edad y el modo de su relación con los personajes y el lenguaje de ese gran libro en su artículo 
Es pues un paradigma religioso y cristiano constituido sobre la base de estas ejemplaridades el que determina, orientándolo, el pensamiento crítico de Mistral. Un pensamiento que rehúye la reclusión mística y proyecta en cambio la potencia crítica de sus ejemplaridades religiosas sobre la vida cotidiana chilena (y, como veremos, sobre el amplio campo de las sociedades modernas de la primera mitad del siglo XX). En "Cristianismo con sentido social", empezaba dándose por objeto la historia misma del cristianismo en América Latina, al que acusaba, como vimos, de no haber sabido ponerse del lado de los pobres, del pueblo, y de no haber asumido sus reclamos de justicia, de reparación económica, cultural y espiritual. Sin embargo, afirmaba al mismo tiempo su convicción de que aún era posible una reacción, un movimiento de "reconquista" de los humildes y su mundo, de los sometidos al poder (en abierto desafío, es claro, a la propuesta "atea" de la Revolución rusa). En ese movimiento de reconquista, y desde ese paradigma religioso, se inscribe la crítica social y cultural que Gabriela Mistral emprende a lo largo de su vida.

Evidentemente, la de los Recados contando a Chile es solo un ejercicio particular, centrado en un escenario histórico específico (dramatizado sin duda por la componente biográfica), de una crítica social y cultural de horizonte mucho más vasto, que cubre América Latina y, en general, el mundo moderno contemporáneo (el de la primera mitad del siglo XX). Fernando Alegría, junto con reconocer desde luego en la Mistral la hegemonía del componente "ético y, en última instancia, religioso", traza una suerte de mapa temático de su pensamiento crítico. Identifica cinco grandes "grupos" temáticos, o "categorías". Aun cuando no agotan el campo ni tampoco me parece muy rigurosa su descripción, constituyen de todos modos un principio aceptable de organización. Distingue: 1. Derechos humanos: "los problemas de las minorías sociales y raciales (mujeres, infancia, trabajadores, indios, judíos, perseguidos políticos"). 2. Cristianismo social: "es decir, la religión y la Iglesia entendidas como formas de responsabilidad social ante la necesidad de justicia económica y política, y por los derechos civiles en la estructura de una democracia liberal". 3. Antitotalitarismo: " antifascismo, antimilitarismo, oposición a todo extremo político". 4. Pacifismo: "apoyo a las tácticas de la antiviolencia de Mahatma Ghandi; ataque a las guerras imperialistas y a la diseminación de armas nucleares". 5. Americanismo: "exaltación de la

"Mi experiencia con la Biblia". En Prosa religiosa de Gabriela Mistral, 39-46. En la misma compilación, un "Recado sobre los judíos", 47-50. 
organización comunal indígena y promoción de la reforma agraria" (Alegría y otros 72-74).

Me detendré a continuación en una rápida lectura de un par de textos donde Gabriela Mistral aborda dos grandes temas sociales y culturales, sin duda recurrentes en su pensamiento crítico sobre el mundo moderno (especialmente cuando se refiere a América Latina), pero que en los Recados parecieran presentarse bajo una forma "originaria", de elaboración rectora, modélica. Uno de estos temas es el de la situación contemporánea de los indígenas en el interior de sociedades modernas, incluido por Alegría en el grupo temático de los "Derechos humanos", y que, en el texto que comentaré, tiene como referente el caso de los mapuches, del pueblo mapuche. El segundo tema, no considerado explícitamente en el esquema de Alegría (pero asociado de una manera implícita al grupo del "Americanismo"), es el de la "tierra" y sus funciones éticas, culturales, sociales desde el punto de vista de visiones condicionadas por el paradigma religioso de la autora. En el tratamiento que hace Gabriela Mistral de ambos temas se introducen reflexiones suficientes para develar determinadas estrategias del poder, colonial y moderno, y sus efectos en las prácticas de la vida cotidiana.

\section{4}

En la mirada de Gabriela Mistral sobre la tierra hay dos focalizaciones entre sí conectadas. Una es estrictamente histórica: la legalización por el poder de una distribución insensata de la tierra (de origen colonial), dándole a algunos la propiedad de grandes latifundios, y a otros, a quienes verdaderamente la trabajan, la propiedad solo de su fuerza de trabajo (mal remunerada además), o la posesión de porciones de extensión muy pequeña, suficientes apenas para reproducir la pobreza, hasta que el campesino, cansado de su servidumbre, malos sueldos, sin escuelas, decide abandonar la tierra e irse a la ciudad (Mistral, Recados 18), acogiéndose así a la promesa, un espejismo en verdad, que comienza a circular desde la segunda mitad del siglo XIX (José L. Romero): la de la ciudad como "el" espacio de vida y de "futuro". Por eso Gabriela Mistral fue siempre activa promotora de la Reforma Agraria en Chile. Decía: "el latifundismo chileno forma parte del bloque de la crueldad conquistadora y colonial" (Mistral, Recados 114). El campo italiano en cambio (que conocía bien), dividido en predios de extensiones razonables y cultivados inteligentemente, le parecía un modelo de distribución que debería 
imitarse en América Latina: le permitiría al campesino tener una vida digna sin necesidad de abandonar la tierra (Ladrón de Guevara 69). No vería en vida esa Reforma, producida solo en la segunda mitad de la década del 60.

No abandonar la tierra: la pérdida es demasiado importante, e irremplazable. El vínculo con la tierra y la figura ejemplar del campesino son el objeto de la segunda focalización, ya no contingente sino esencial, de validez permanente. En efecto, el vínculo con la tierra, para Gabriela Mistral, es el lugar de una apertura a la trascendencia religiosa del hombre y de las cosas, por la cual la rosa es "algo más" que una rosa y la montaña, "algo más" que una montaña. El vínculo con la tierra y la apertura a la que da lugar, son algo tan necesario y definitivo, que todo lo demás se desvalora sin ellos. Y es aquí, a propósito de este vínculo, y del campesino cuya vida da cuenta ejemplar de él, cuando la subjetividad de Gabriela Mistral aparece más intensamente removida y conmovida, ya sea bajo la forma de la celebración del diálogo vincular del hombre con la tierra, o bajo la forma de la crítica a los obstáculos, cualesquiera sean (políticos, económicos), que lo impidan, lo subordinen o lo menosprecien. Y es que en ese diálogo se pone en juego su memoria biográfica: la memoria de su infancia y de su primera juventud, donde el vínculo parece haber asistido a su epifanía. Una memoria que no se cansa de dar testimonio de vivencias, de imágenes inundadas por el sentimiento de felicidad como una sintonía con la tierra, con quienes la habitan y la trabajan. Para Gabriela Mistral, esa sintonía religiosa es expresión de la alianza del hombre con el mundo, con un destino de vida donde el hombre y las cosas, sin dejar de ser cuerpo o materialidad, son a la vez figuras que se trascienden a sí mismas en un "algo más" de sentido, que para ella es el "más" de la presencia de Dios.

"Toda cultura empieza por la tierra" (Mistral, Recados 17), afirma. Sin duda, la cultura en la que piensa Gabriela Mistral no es la de la modernidad como cultura de la vida cotidiana, históricamente urbana en primer lugar, y no rural, e históricamente disolvente, al simple contacto de lo incompatible, de las culturas asociadas a la tierra. Más aún: la economía moderna, capitalista, y su tecnología de producción de mercancías (incluyendo las tecnologías publicitarias del turismo), se han desarrollado siempre y en todas partes, de manera directa o mediada, a expensas de la tierra, de sus especies animales y vegetales, de las culturas y de la cotidianeidad que funda. Los Recados hablan, por ejemplo, de un tipo de producción, en manos de capitales ingleses en las primeras décadas, con un historial particularmente infame: la minería, dominante en la economía chilena desde la segunda mitad del siglo XIX hasta hoy. Ya al empezar el siglo XX, la mina había pasado a ser el símbolo de una 
explotación del trabajador que simplemente escandalizaba a la conciencia cristiana. Un trabajador campesino en la mayoría de los casos, convertido en minero por necesidad o falsas expectativas, que veía sometido al escarnio el orden cultural ligado a la tierra de donde venía. La mina era un espacio de vida y de trabajo sometido a una racionalidad primitiva, salvaje, sin control de la ley, más bien amparada por el poder político de la nueva burguesía chilena, formada a lo largo del siglo XIX, después de la Independencia. Gabriela Mistral diría: "Y yo he acabado por odiar la mina, como quien odia a un enemigo de su familia" (Mistral, Recados 22). Y antes, Baldomero Lillo, en sus cuentos de 1904, había hecho de la mina un espacio infernal, y de los mineros, unos condenados sin remisión. No constituye para nada una exageración ver en este minero una figura tan paradigmática de cómo el poder moderno y la racionalidad de sus métodos pueden llevar la "condición humana" a un estado fronterizo, a límites de indistinción entre lo humano y lo no humano, como la figura del "musulmán", pensada por Agamben a propósito de los campos de concentración nazis.

Si toda cultura implica necesariamente un determinado orden social que permita su producción y circulación, y aun cuando se conceda que la mina es un caso de "desviación", de aberración focalizada, no necesaria al sistema, el modelo de ese orden social, para Gabriela Mistral, no es desde luego el modelo burgués, el de la vida cotidiana de la ciudad moderna, que ella bien conocía en su existencia errabunda. Por el contrario, para ella el modelo estaba en otro lugar, y hecho de elementos de otra naturaleza: su modelo es el orden de la aldea como un orden comunitario. El modelo del que su memoria biográfica recupera la experiencia viva, llena de sentido, de presencia para sí: es el orden de las pequeñas comunidades del Valle de Elqui donde nació. Comunidad de lenguaje, de lugares de referencia, de rostros, de relatos ejemplares, de prácticas de vida y de trabajo. En última instancia, comunidad de la tierra, de la cultura que ella hace posible. Al orden de esta comunidad aldeana se abre la memoria de Gabriela Mistral como a una "reminiscencia" platónica, palabra esta última por lo demás familiar para ella.

La aldea, es decir, el orden y el vínculo a los que, habitándola, se entra, no es por supuesto un patrimonio exclusivo de la ruralidad cristiana evocada por la memoria de la infancia de Gabriela Mistral. Es igualmente la aldea de otras viejas tradiciones culturales, ni modernas ni occidentales, de Asia, África. Pero es también una aldea más próxima, de dentro y fuera de Chile, en América Latina: la aldea indígena, espacio de despliegue asimismo de un orden fundado en una cultura de la tierra. La misma crítica a la vida cotidiana 
chilena moderna donde los valores humanos de la vieja aldea cristiana se deforman, envilecen o se hacen imposible, se repite, en Gabriela Mistral, cuando ve en las calles de la ciudad chilena, en el mismo espacio de vida cotidiana, pero en una convivencia desde lugares profundamente desiguales, los rostros y los cuerpos vejados de los mapuches, náufragos en la ciudad, $\mathrm{y}$, en sus tierras ancestrales, habitantes fantasmales de una aldea agredida y mutilada tanto por el poder colonial como por el poder republicano, moderno, con igual violencia, aunque tal vez este último lo haya hecho de una manera especialmente insidiosa (más deliberada, calculada, racional).

De pronto, en una crónica publicada en 1932 con el título de "Música araucana" (Mistral, Recados 80-90), el tono de la voz se hace oscuro, se llena de resonancias trágicas, cuando la palabra tiene que dar cuenta de una realidad que la sobrepasa, que la escandaliza, y que la sociedad sin embargo ha estado produciendo y reproduciendo a lo largo de siglos, como ciega o sorda. En esta crónica recuerda su estadía en el sur de Chile, en la capital de la Araucanía, la ciudad de Temuco, a donde había llegado como Directora de un Liceo. En el camino que hacía diariamente hacia su Liceo debía pasar frente a un Juzgado, y solía ver entonces, en la calle, a algunos mapuches, esperando. Mediante un procedimiento metonímico, a partir de lo que ve y de lo cual da testimonio (pero también de su saber de la historia de Chile), ofrece una imagen del todo, del pueblo mapuche. La imagen que construye y le entrega a sus lectores es la de un pueblo abatido, humillado, reducido a ser su propia ausencia. Se falta a sí mismo. Las voces de las mujeres que de pronto oye, que hablan entre sí en su lengua originaria (el mapudungún), un habla que suena como arrullo de palomas, le transmiten a la vez la ternura y el desamparo. Es la imagen de un pueblo que ha sido despojado de su diferencia, de su identidad, de su dignidad, hasta tal punto que Gabriela Mistral se refiere a él como la "raza gris". Gris: el color de lo sin color: el color de una humanidad despojada de su humanidad. Una raza gris: "la mancha de águilas cenicientas que vive Bíobío abajo, si vivir es eso y no acabarse". El mestizaje criollo sería "igual o peor que la casta ibera hacia la raza materna (...), arrancando a la indiada de su región para dispersarla y enloquecerla con la pérdida del suelo". Y en los hombres indígenas ve unas "caras viriles, cansadas del mayor cansancio que pueda verse en este mundo". Para ella el pueblo judío siempre fue la figura por excelencia del acosado y perseguido. No extraña entonces que relacione indirectamente al pueblo mapuche con el judío, cuando dice del primero que es "el más aplastado por el silencio, que es peor que un "pogrom”. La voz de Gabriela Mistral en esta crónica 
brota de un silencio abrumador: el de la vida cotidiana chilena que parece transcurrir, en Temuco o en Santiago, como si nadie viera lo que ella ve y hace visible a sus lectores.

Desde la Conquista y la Colonia viene denunciándose la conversión infame de los pueblos indígenas en objeto de saqueo, aniquilación y servidumbre forzada. Las Casas ha sido la voz más sonora de esta denuncia en los primeros tiempos de la Colonia. En Chile, y ya en el siglo XX, Aurelio Díaz Meza, periodista de un diario de Santiago, El Diario Ilustrado, daba cuenta del estado de la comunidad mapuche después de la "pacificación" de la Araucanía llevada a cabo por el ejército en la década de 1880 (una nueva agresión, ahora "republicana", al pueblo mapuche). En 1907 publica su libro En la Araucanía: un verdadero reportaje, notablemente escrito, al "parlamento" que ese año reúne a los caciques en Coz-Coz, provincia de Panguipulli. Transcribe los discursos de los caciques y, una vez terminado el parlamento, recoge de los propios indígenas el relato pormenorizado de los abusos, engaños, a veces muertes, y las complicidades de jueces y "colonos" para arrebatarles sus tierras. En la época republicana el pueblo mapuche desde luego no tiene el privilegio de estas agresiones: por esos años los pueblos del extremo sur sufrían los ataques de unos colonos ya desprovistos de razones religiosas como justificación, que operaban con una racionalidad desnuda y cínica. Joaquín Edwards Bello publicaba, en 1911, en su libro Tres meses en Río de Janeiro, una entrevista a un sacerdote salesiano que hablaba de cómo había sido testigo de las prácticas habituales de asesinatos de miembros de las poblaciones indígenas del extremo sur de Chile, la zona de Magallanes, y cómo esas prácticas eran propiciadas y bien remuneradas por dueños de estancias, para quienes el indio era un estorbo para su dominación (Edwards 179-189).

La crónica de Gabriela Mistral, si bien posterior al libro de Díaz Mesa y a la entrevista de Joaquín Edwards, es la primera en ofrecer una imagen de desolación de un pueblo originario, el mapuche, construida desde el interior de la vida urbana moderna, con elementos de una experiencia cotidiana, y desde una sensibilidad y una ética que ya son las nuestras. No se trata pues de hablar de un pueblo originario a través de la distancia, de dar un testimonio verídico de las condiciones en que viven o sobreviven en sus tierras. Se trata por el contrario de la presencia del indígena en la ciudad, en la calle de la ciudad, del silencio que lo envuelve como el signo de una indiferencia (sin duda largamente promovida por las estrategias del poder) que por sí misma establece una relación de complicidad con el Estado y la historia de este 
pueblo. En la voz de Gabriela Mistral, la voz crítica de una conciencia ética e histórica, hay un desgarro que se siente como percibido por primera vez. No volveremos a oír esa voz inaugural, su tono ensombrecido, hasta la segunda mitad de la década de 1950 y la década siguiente, con el canto y la poesía de Violeta Parra. Canciones suyas como "Arauco tiene una pena", "Nguillatún" (Manns 107-108 y 122-123), se inscriben claramente en la línea abierta por Gabriela Mistral en su crónica. Un eco reciente de esas canciones y de esta crónica se puede oír también en el disco Aire puro, del grupo de músicos chilenos Congreso, en la canción "Aroma de canelos": otra vez, como en la Mistral, el desgarro de la voz (del que canta) y otra vez, en el trasfondo, una mujer mapuche que dice su lamento en mapudungún.

La idea de Gabriela Mistral de que en la alianza del hombre con la tierra se teje el tramado de toda auténtica cultura comunitaria (una idea ésta, como dije, para nada moderna) tuvo, entre los escritores chilenos, una recepción particularmente fecunda en Luis Oyarzún. Ella lo conocía, intercambió cartas con él, y fue él quien leyó el discurso de bienvenida a la Universidad de Chile cuando Gabriela Mistral vino a Chile en 1954. Oyarzún publicó poesía y ensayos. Su libro Temas de la cultura chilena, de 1968, es ya un clásico del ensayismo literario chileno. Pero es su extenso Diario, obra fundamental en la literatura chilena moderna y en la historia del género en lengua española, el que mejor registra la filiación mistraliana de su pensamiento, sobre todo en su crítica a la vida cotidiana de la sociedad chilena y a la historia de las relaciones de ésta con la tierra, pero también evidente en otros planos. Por ejemplo, en el de la valoración poética. Oyarzún confiesa en el Diario su íntima cercanía con la poesía de Mistral, frente a una admiración más bien fría, con reproches estéticos y políticos, de la poesía de Neruda. Dice: "ella no cierra el mundo, transfigura las visiones de la tierra en exaltación ultraterrena, expresa con pasión los deseos más hondos y eternos" (Oyarzún 313). Neruda en cambio, marxista, materialista, lo "cierraría" en la medida en que lo historiza, reduciéndolo al juego de sus propias fuerzas, es decir, expulsando de él toda trascendencia. Por el contrario, en Mistral el hombre no consuma su destino en un puro y determinado modo de aparecer y ser en el tiempo histórico. Hay un "algo más", irreductible al absoluto de la historia, que toma forma en la sintonía espiritual (o religiosa) del hombre con la tierra, 
con el todo, con el universo, con Dios: es entonces cuando el hombre y su mundo se "abren" a su propia trascendencia, y es así, por esa vía, como de algún modo se salva, en el sentido de que se cumple.

Oyarzún hace suyo el sentido cultural y ético de aquel vínculo originario, y lo convierte en el modelo por excelencia de una renovada crítica de la vida cotidiana chilena ( $\mathrm{y}$, de paso, de una crítica de las promesas sociales "libertarias" de la modernidad). Pero desplaza los énfasis del pensamiento de Gabriela Mistral y los resitúa dentro de una visión de horizontes más amplios y, en algunos aspectos, de desarrollo reflexivo conceptualmente más explícito. Para empezar, él no pone un acento de alguna manera restrictivo en la "tierra" en cuanto espacio próximo, ya "domesticado", sino en la tierra en un sentido más inclusivo: la tierra como "naturaleza". De hecho, cuando recupera la palabra "tierra", para ponerla en un lugar tan visible como el título de un libro, el de su libro póstumo Defensa de la tierra, la usa para nombrar, perturbado, la naturaleza en una dimensión genérica y planetaria: es ella la que ha sido puesta, por el proyecto "defensa" a la que exhorta el título.

Pero el núcleo esencial del pensamiento de Gabriela Mistral sobre el vínculo con la tierra como el lugar originario de la cultura, queda intacto y activo en las anotaciones del Diario de Oyarzún. En otras palabras, asume en plenitud la afirmación de Mistral: "Toda cultura empieza por la tierra”. Lo que está en juego en esta relación hombre-naturaleza, en último término, para Oyarzún, es el eros: el amor a la naturaleza, y el reconocimiento de que en ese amor se juega un destino común. En Oyarzún como en Gabriela Mistral, el amor a la tierra, a la naturaleza de pronto se desborda en tentaciones místicas, de unidad, de "fusión" con el todo. También da lugar a múltiples celebraciones de determinadas formas particularmente felices de aparecérseles la naturaleza. En uno y en otro son comunes las descripciones de árboles nativos, como si se tratara de una fiesta sensorial orquestada por el lenguaje, por ejemplo las descripciones del algarrobo en Mistral (Mistral, Recados 115) y del coigüe en Oyarzún (483-484), que le ofrecen al lector, con su lenguaje lírico, imágenes en cuya belleza pareciera volverse transparente, por un momento y como en un rito verbal, la verdad del destino común de hombre y naturaleza.

Este mismo amor a la naturaleza es la razón profunda de la crítica de Oyarzún a la vida cotidiana chilena (la de su presente y la del pasado). Ve en ella la reiteración de una ausencia: la ausencia de una cultura histórica formada en el diálogo amoroso con la naturaleza, de los rituales colectivos, comunitarios, que den testimonio de ella. El fantasma de esta ausencia marca oscuramente las relaciones interpersonales y las del hombre con el espacio inmediato en 
que vive. En vez del gesto de verdadera "civilización", de humanidad gentil, la vida cotidiana chilena más bien pone en escena lo contrario: el gesto agresivo. El chileno, dice Oyarzún, "odia” los árboles (Oyarzún 308-309). Destruye la naturaleza, la "afea" (y se "afea") o simplemente la ignora con una porfiada constancia. En este sentido, la "racionalidad" (Weber) de las sociedades modernas o burguesas, su tecnología como expresión e instrumento de dominio y al mismo tiempo de separación de la naturaleza, pareciera haber encontrado en la sociedad chilena predisposiciones, atavismos propicios. $\mathrm{Y}$ tal vez aquí, en este punto, la mirada de Oyarzún sea aún más radical que la de su inspiradora.

Las zonas de encuentro entre estos dos escritores no se reducen a las señaladas y descritas tan brevemente. Hay una imposible de omitir aquí: el viaje. En 1922 Gabriela Mistral salió de Chile por primera vez, invitada a México. Desde entonces, solo dos o tres veces volvió a Chile. La última fue en 1954, después de 16 años y 3 antes de su muerte. Vivió en Italia, España, Portugal, Brasil, Estados Unidos. Esta persistencia en el viaje, en la distancia del afuera que el viaje introduce, no es más que la exteriorización biográfica del viaje que todos los grandes creadores, salgan o no de su país, tienen que hacer necesariamente. A veces el movimiento interior del viaje hacia un afuera es nombrado también con la palabra "exilio". En cualquier caso, se trata de alguna manera de un "perder" lo dado (lengua enseñada y su territorio, su vida cotidiana) como condición para "encontrar", en su invención poética, otra lengua desde donde decir la primera (y su territorio, su vida cotidiana). Si bien la postulación de esta dialéctica parece indiscutible para la poesía de $\mathrm{Mistral}^{7}$, ¿es válida asimismo para la escritura de sus Recados contando a Chile? Creo que sí, pero de un modo específico. Desde luego, la prosa de Mistral, esa con que ella finge reproducir la lengua oral, es una lengua literaria, un artificio. Y el Chile de sus Recados es uno que ella dibuja a partir de la ausencia de su objeto, de las experiencias transfiguradas desde la distancia y la memoria: desde un afuera. Los recados sobre Chile y su vida cotidiana (urbana o rural) están escritos desde fuera de Chile, desde alguno de los diversos países donde vivió, y los materiales de la experiencia con que construye sus imágenes son los que aporta la memoria. Una memoria tan desprendida ya de lo dado, tan distante de su objeto, que las imágenes a las que

7 Sobre esta dialéctica del encontrarse perdiéndose, véase el análisis de Eugenio Florit en "Paisaje y poesía en Gabriela Mistral". 
contribuye a construir aparecen investidas por una suerte de aura espectral, fantasmagórica, vecina del mito o la leyenda (sobre todo las imágenes de la infancia), pero sin perder su capacidad para iluminar los vacíos, las ausencias de lo real, de lo histórico ${ }^{8}$.

Oyarzún fue otro gran viajero. Como Mistral, quería también "verlo todo". A tal punto, que la escritura de su Diario íntimo, sin que ponga nunca en cuestión las propiedades del género, puede leerse como un singular "diario de viaje". Pero hay diferencias mayores en el modo de darse el viaje en uno y en otro. Mistral viajaba, diría, para no volver, o volver sin volver, no solo por la brevedad del tiempo de permanencia en sus escasos retornos sino porque era un volver a un lugar ya perdido, o que se vive como tal. El viaje de Oyarzún en cambio era un ir y venir continuo, dentro de Chile, entre Chile y América Latina, Estados Unidos, Europa, Asia. Aun cuando en su Diario intimo hay momentos en que asoma la dialéctica del perderse-encontrarse, lo suyo no es un gesto instalado, una apuesta sostenida: es más bien un juego, una seducción virtual, sin entrega a la misma. No hay en Oyarzún lo que hay en Mistral: la vivencia de los límites extremos, de las pérdidas absolutas, de la muerte, de los impulsos suicidas. Oyarzún va y viene, con una mirada siempre terrenal, perspicaz, sabia e ilustrada, que se abre a las cosas y a las diversas culturas, atento a las escenas que ratifican el pacto del hombre con la naturaleza, para celebrarlas, o que hablan de su ruptura, para dar avisos, como si el mundo le hubiera sido dado al hombre para su goce. De sus viajes regresa a Chile, a ver y describir, una vez más, hasta el infinito, el milagro de su naturaleza, y a registrar cómo el chileno se empeña en destruirla, en vivir a sus espaldas, entregado a una intemperie cultural (espiritual) constante.

\section{BIBLIOGRAFÍA}

Agamben, Giorgio. Lo que queda de Auschwitz. Traducción de Antonio Gimeno. Valencia: Pre-Textos, 2000.

${ }^{8}$ En Chile y en años más próximos a nosotros, han pensado de manera penetrante el tema del viaje (y del exilio) en relación con la creación literaria escritores como José Donoso y Roberto Bolaño, también ellos dos habitantes excepcionales de esas "otras" patrias. José Donoso en "Las lenguas del viaje", "Idioma y retorno" (Artículos de incierta necesidad) y Roberto Bolaño en "Literatura y exilio", "Exilios" (Entre paréntesis). 
Alegría, Fernando. “Aspectos ideológicos de los Recados de Gabriela Mistral”. En Fernando Alegría y otros. Gabriela Mistral. Introducción de Mirella Servodio y Marcelo Coddou. México: Universidad Veracruzana, 1980. 70-79.

Benjamin, Walter. La obra de arte en la época de su reproductibilidad técnica. Traducción de Andrés E. Weikert. México: Editorial Itaca, 2003.

Bolaño, Roberto. "Literatura y exilio" y "Exilios". Entre paréntesis. Edición de Ignacio Echeverría. Barcelona: Editorial Anagrama, 2004. 40-46 y 49-58.

Corominas, Joan. Breve diccionario etimológico de la lengua castellana. Madrid: Editorial Gredos, 1961.

Díaz Meza, Aurelio. En la Araucanía. Breve Relación del último Parlamento araucano de Coz-Coz, 18 de enero de 1907. Santiago: Imprenta El Diario Ilustrado, 1907.

Donoso, José. "Las lenguas del viaje", "Idioma y retorno". Artículos de incierta necesidad. Edición y prólogo de Cecilia García Huidobro. Santiago: Aguilar Chilena de Ediciones, 1998. 65-73 y 212-218.

Eagleton, Terry. Ideología. Una introducción. Traducción de Jorge Vigil Rubio. Barcelona: Ediciones Paidós, 2005.

Edwards Bello, Joaquín. "Una entrevista interesante (en alta mar)". Tres meses en Río de Janeiro. Santiago: Aguilar Chilena de Ediciones, 2004. 179-189.

Florit, Eugenio. "Paisaje y poesía en Gabriela Mistral”. En Fernando Alegría y otros. Gabriela Mistral. Introducción de Mirella Servodio y Marcelo Coddou. México: Universidad Veracruzana, 1980. 61-69.

Garrido Gallardo, Miguel A. (comp.). Teoría de los géneros. Madrid: Arco/Libros, 1988.

Ladrón de Guevara, Matilde. Gabriela Mistral. Rebelde magnifica. Buenos Aires: Editorial Losada, 1962.

Manns, Patricio. Violeta Parra. Barcelona: Ediciones Júcar, 1984.

Mistral, Gabriela. Recados contando a Chile. Selección, prólogo y notas de Alfonso M. Escudero, O.S.A. Santiago: Editorial del Pacífico, 1957.

Prosa religiosa. Edición y notas de Luis Vargas Saavedra. Santiago: Editorial Andrés Bello, 1978.

Oyarzún, Luis. Temas de la cultura chilena. Santiago: Editorial Universitaria, 1967.

Defensa de la tierra. Santiago: Editorial Universitaria, 1973.

Diario íntimo. Edición y prólogo de Leonidas Morales T. Santiago: Departamento de Estudios Humanísticos, Universidad de Chile, 1995. 